\title{
Ruminal degradability of Virginia fanpetals (Sida hermaphrodita) herbage and silage depending on the harvest time
}

\author{
J.P. Michalski ${ }^{1}{ }^{4}$, M. Borsuk², Z. Nogalskiं ${ }^{3}$ M. Baranowska², A. Krawczyńska' and C. Purwin ${ }^{2}$ \\ ${ }^{1}$ The Kielanowski Institute of Animal Physiology of Nutrition Polish Academy of Sciences \\ Instytucka 3, 05-110 Jabłonna \\ University of Warmia and Mazury in Olsztyn, \\ ${ }^{2}$ Department of Animal Nutrition and Feed Science, ${ }^{3}$ Department of Cattle Breeding and Milk Evaluation \\ Oczapowskiego 5, 10-719 Olsztyn, Poland
}

KEY WORDS: Virginia fanpetals, silage, ruminal degradability, Sida hermaphrodita

Received: 12 November 2020

Revised: 19 December 2020

Accepted: 21 December 2020
${ }^{4}$ Corresponding author:

e-mail: j.p.michalski@op.pl
ABSTRACT. Virginia fanpetals (Sida hermaphrodita) as a crop plant is characterized by high biomass yield, high protein content and good fibre composition. The aim of the study was to evaluate ruminal degradability of Virginia fanpetals herbage and silage of first swath and regrowth. In situ ruminal degradability was determined using 2 rumen fistulated heifers fed standard diet. Degradation was estimated using nylon bags with dried feed placed in the rumen for 2, 4, 8, 16, 24, 48 and $72 \mathrm{~h}$. Ensiling accelerated the dry matter (DM) degradability of first swath in the first hours of incubation and slowed down in the following hours. Ensiling the regrowth accelerated DM degradability both in the initial and final hours. In the silage from regrowth effective rumen degradability (ERD) of DM and neutral detergent fibre (NDF) were higher than in herbage. Ensiling accelerated crude protein (CP) degradability in both swaths so ERD of $\mathrm{CP}$ was higher in both silages. The results of the present study show that Virginia fanpetals green fodder preserved by ensiling can be successfully used as supplementary forage for ruminants. In particular, first swath silage, due to its high protein content, can be used instead of legume silage in diets for cattle, and also it can reduce the need to use high-protein concentrate. However, ensiling caused significant acceleration of rumen protein degradability, which with unchanged DM and fibre degradability rate is not a desirable effect and requires simultaneous delivery of easily digestible carbohydrates into diets.

\section{Introduction}

Virginia fanpetals (Sida hermaphrodita L.), also known as Virginia mallow), is cultivated in Europe as a source of biomass used for energy purposes. In terms of protein content, Virginia fanpetals is as good as the legume plants, widely used in ruminant nutrition, or even exceeds them. Moreover, Virginia fanpetals leaves contain a relatively high content of essential amino acids, especially lysine and methionine (Tarkowski and Truchliński, 2011). Contrary to legume plants, Virginia fanpetals does not contain saponins, phytoestrogens, lectins or cyanogenic glucosides, and antinutritional substances present in Virginia fanpetals are not a threat to animal health (Borkowska, 1994). On the other hand, Virginia fanpetals contains a rutin (Bandyukova and Ligai, 1987), a flavonoid that inhibits the growth of many strains of bacteria and fungi (Ganeshpurkar and Saluja, 2017).

Silage produced from Virginia fanpetals is a good substrate for biogas production (Oleszek 
et al., 2013). The results of preliminary studies indicate that Virginia fanpetals silages also have a high nutritional value and are gladly consumed by ruminants. Virginia fanpetals silages could be a valuable feed for ruminants, but such their usage is completely underestimated. Previous studies on the use of preserved feed from Virginia fanpetals in the nutrition of ruminants have been limited to the use of dehydrated herbage and protein-fibrous extrudates as substitutes for concentrated mixtures in diets for fattened lambs and dairy cows (Tarkowski, 2008). The use of dehydrated herbage allowed to eliminate the concentrate from rations for fattened lambs without reducing the slaughter efficiency, and the usage of the extrudate in the feeding of cows increased the milk yield and protein content in milk (Tarkowski, 2008). However, the production of dehydrated herbage and extrudate is an energy-consuming process, while the production of silage is the most frequently used method of green forage preservation in European conditions. By ensiling, regardless of weather conditions, a good quality fodder with high nutritional value is obtained. Silage produced from highprotein crops, such as Virginia fanpetals, could be the basic source of nitrogen compounds for ruminants, reducing the need to use high-protein concentrates. However, nitrogen compounds from highprotein plants silages are not efficiently utilized due to the excessive rumen degradability of protein. On the other hand, too low ruminal feed degradability causes a reduced dry matter (DM) intake and, consequently, low energy intake (Van Soest, 1994).

In Europe, the most important high-protein feed used in ruminant nutrition are legumes, including alfalfa (Medicago sativa), which is an alternative for imported soyabean meal. Alfalfa silage contains a significant amount of protein, so it may be a primary source of nitrogen compounds for ruminants reducing the need of using a high-protein concentrate. This feed is very important in ruminant feeding, but intensive processes of proteolysis and deamination during ensiling lead to increased free amino acids and ammonia nitrogen contents and decreased levels of protein and peptide nitrogen decreasing nutritional value of silage (Sullivan et al., 2008). Such change in the profile of nitrogen fraction is disadvantageous as it reduces the feed nitrogen compounds utilization efficiency (Calsamiglia et al., 2010). It also results in increased loss of nitrogen in the urine, has an environmental footprint (Frank et al., 2002) and requires diet supplementation with other sources of proteins. Content of saponins and phytoestrogens as well as unfavourable changes ob- served in ensiled alfalfa induce the search for alfalfa substitutes among high-protein crops, including Virginia fanpetals.

In our previous research the suitability of Virginia fanpetals for ensilage, the good fermentation profile and high microbiological quality of the silage produced from the first swath was confirmed (Fijałkowska et al., 2017). Virginia fanpetals having similar protein content as alfalfa could be an important source of high-protein roughage for cattle. Unlike alfalfa, Virginia fanpetals can be successfully grown in soils poor in organic matter $(\mathrm{OM})$ and nutrients (Manning et al., 2015). We have previously shown that complete replacing alfalfa silage in rations for dairy cows with Virginia fanpetals silage harvested in the early vegetation stage does not reduce milk yield (Purwin et al., 2020). Therefore it was justified to investigate the ruminal degradability of Virginia fanpetals herbage and silage depending on the harvest time and to assess their nutritive values. The comparison with alfalfa silage was also included.

\section{Material and methods}

The animal protocol and the number of animals used in the present study were consistent with regulations of the Local Ethics Committee for Animal Experiments (Resolution No. 73/2015, Warsaw, Poland), and the study was carried out in accordance with EU Directive 2010/63/EU on the protection of animals used for scientific purposes (OJEU, 2010).

\section{Herbage and silage}

The experiment was conducted in 2015 in northeastern Poland $\left(53^{\circ} 05^{\prime} 27.7^{\prime \prime} \mathrm{N}, 21^{\circ} 11^{\prime} 47.5^{\prime \prime} \mathrm{E}\right)$. The experimental material was the first swath of Virginia fanpetals harvested in the bud formation stage on 11 June and the regrowth harvested on 12 September, 2015, with the Claas Jaguar 930 self-propelled forage harvester (CLAAS KGaA mbH, Harsewinkel, Germany) equipped with the Kemper 360 attachment (KEMPER GmbH \& Co. KG, Stadtlohn, Germany). At the beginning of the growing season, plants were fertilized with $100 \mathrm{~kg} \mathrm{~N} / \mathrm{ha}, 50 \mathrm{~kg} \mathrm{~K} \mathrm{O}_{2} / \mathrm{ha}$ and $80 \mathrm{~kg}$ $\mathrm{P}_{2} \mathrm{O}_{5} /$ ha. Herbage samples were collected before ensiling. Virginia fanpetals biomass was ensiled without previous wilting in 220-liter standard open-head high-density polyethylene (HDPE) drums (Brenntag $\mathrm{GmbH}$, Essen, Germany) without drainage holes, and was compressed to the density of $830 \mathrm{~kg}$ fresh mass $(\mathrm{FM}) / \mathrm{m}^{3}$. After 90 days, silage 
samples were collected with a probe $(\varnothing 80 \mathrm{~mm})$ along the entire length of the drums, dried at $60^{\circ} \mathrm{C}$ or $48 \mathrm{~h}$ in the Binder FED 115 dryer (Binder GmbH, Tuttlingen, Germany), and ground in the Retsch SK 100 mill (Retsch GmbH, Haan, Germany) to a $1-\mathrm{mm}$ particle size. The obtained samples were frozen at $-25^{\circ} \mathrm{C}$.

\section{Chemical analysis of herbage and silage}

Herbage and silage samples, as well as their dried samples used for in situ rumen degradability, were assayed for proximate chemical composition: $\mathrm{DM}$ (method 934.01), crude protein $(\mathrm{CP} ; \mathrm{N} \times 6.25$, method 976.05), crude fibre (method 978.10), ether extract (method 920.39) and crude ash (method 942.05), as described by AOAC International (2005), water-soluble carbohydrates (WSC) by the anthrone method (Thomas, 1977), neutral detergent fibre (NDF) assayed with heat-stable amylase and expressed exclusive of residual ash, acid detergent fibre (ADF) expressed exclusive of residual ash and acid detergent lignin (ADL) according to Van Soest et al. (1991) using the ANKOM220 fibre analyser (ANKOM Technology Corp., Macedon, NY, USA). The chemical composition and fermentation products of the first swath Virginia fanpetals (herbage and silage) and alfalfa silage were reported in detail in our previous papers (Purwin et al., 2014; Fijałkowska et al., 2017). The chemical composition of herbages, silages are presented in Table 1 and dried samples used for in situ rumen degradability are presented in Table 2 .

Table 1. Chemical composition of Virginia fanpetals herbages (first swath and regrowth) and their silages, and alfalfa silage, $\mathrm{g} / \mathrm{kg}$ dry matter

\begin{tabular}{|c|c|c|c|c|c|}
\hline \multirow{2}{*}{ Indices } & \multicolumn{4}{|c|}{ Virginia fanpetals } & \multirow{2}{*}{$\begin{array}{l}\text { Alfalfa } \\
\text { silage }^{2}\end{array}$} \\
\hline & herbage- $1^{\mathrm{st1}}$ & silage- $1^{\text {st }}$ & herbage- $2^{\text {nd }}$ & silage-2 ${ }^{\text {nd }}$ & \\
\hline $\mathrm{DM}, \mathrm{g} / \mathrm{kg}$ & 197 & 199 & 324 & 352 & 420 \\
\hline $\mathrm{CP}$ & 199 & 176 & 100 & 97 & 175 \\
\hline Crude ash & 84 & 89 & 60 & 78 & 101 \\
\hline WSC & 73 & 6.0 & 72 & 8.7 & - \\
\hline NDF & 403 & 378 & 506 & 516 & 511 \\
\hline ADF & 308 & 314 & 373 & 384 & 404 \\
\hline $\mathrm{ADL}$ & 38 & 43 & 69 & 68 & 105 \\
\hline
\end{tabular}

${ }^{1}$ data published in our previous paper (Fijałkowska et al., 2017);

${ }^{2}$ chemical composition of alfalfa silage reported in our previous paper (Purwin et al., 2014); DM - dry matter, CP - crude protein, WSC - water soluble carbohydrates, NDF - neutral detergent fibre, $A D F$ - acid detergent fibre, $A D L$ - acid detergent lignin

\section{Rumen degradability of herbage and silage}

In situ rumen degradability of Virginia fanpetals herbages (first swath and regrowth) and their silages was determined by the method of Michalet-
Table 2. Chemical composition of Virginia fanpetals herbages (first swath and regrowth) and dried samples of their silages used for in situ rumen degradability, \%

\begin{tabular}{lcccc}
\hline \multirow{2}{*}{ Indices } & \multicolumn{4}{l}{ Virginia fanpetals } \\
\cline { 2 - 5 } & herbage-1 & st & & \\
DM & 90.0 & 81.4 & 91.9 & 92.5 \\
CP & 17.4 & 15.7 & 9.3 & 8.9 \\
Ether extract & 1.3 & 2.4 & 1.9 & 1.9 \\
Crude fibre & 22.1 & 24.3 & 28.7 & 30.8 \\
Crude ash & 7.8 & 7.0 & 5.9 & 6.7 \\
NDF & 36.2 & 34.5 & 46.8 & 42.7 \\
ADF & 27.7 & 30.3 & 35.3 & 37.1 \\
ADL & 3.1 & 5.0 & 6.7 & 6.3 \\
\hline
\end{tabular}

$\mathrm{DM}$ - dry matter, $\mathrm{CP}$ - crude protein, NDF - neutral detergent fibre, ADF - acid detergent fibre, $A D L$ - acid detergent lignin

Doreau et al. (1987), using 2 rumen fistulated Jersey heifers fed standard diets based on the INRA (2007) recommendations. The analysis was performed at The Kielanowski Institute of Animal Physiology and Nutrition, Polish Academy of Sciences (Jabłonna, Poland). Approximately 3 of dried and ground samples of each forage were placed in the nylon bags. The chemical composition of samples is presented in Table 2. The number of bags with samples and incubation times were as follows: $2 \mathrm{~h}-3$ bags, $4 \mathrm{~h}-3-4$ bags, $8-24 \mathrm{~h}-3-5$ bags, $48 \mathrm{~h}-5-7$ bags, $72 \mathrm{~h}-8-10$ bags per heifer. All bags used in each period of incubation were placed in the rumen and removed at the determined time points. After incubation, the bags were rinsed under cold tap water to remove excess ruminal content, and washed in an automatic washing machine (three cycles of cold water rinsing and spinning, total time of $18 \mathrm{~min})$. At time point $0 \mathrm{~h}(3$ samples of each forage), bags were not incubated but only washed in an automatic washing machine. The obtained samples of the residues were assayed for the content of DM (method 934.01) and $\mathrm{CP}(\mathrm{N} \times 6.25$, method 976.05) as described by AOAC International (2005), and NDF according to Van Soest et al. (1991).

In situ rumen degradability of alfalfa silage cv. Alba ensiled without additives after wilting in bale (density about $189 \mathrm{~kg} \mathrm{DM} / \mathrm{m}^{3}$ ) was performed at The Kielanowski Institute of Animal Physiology and Nutrition, Polish Academy of Sciences (Jabłonna, Poland) by the same staff and determined by the same method using 3 rumen fistulated Jersey heifers and was published by Purwin et al. (2014).

\section{Calculations and statistical analyses}

Content of DM was corrected using the equation proposed by Porter and Murray (2001) for drying 
at $60{ }^{\circ} \mathrm{C}$. The rumen degradabilities of DM, CP and NDF were calculated for Virginia fanpetals herbages (first swath and regrowth) and their silages. The effective rumen degradability (ERD) and degradability rate constants $(A, B, C)$ were determined according to the methods of Ørskov and McDonald (1979). Based on the applied methodology, a rumen outflow rate $(\mathrm{k})$ of $6 \%$ per $\mathrm{h}$ was assumed. The effect of the ensiling process on Virginia fanpetals ruminal degradability was analysed. Degradability results are presented as arithmetic means for individual incubation times.

Calculations and graphs were performed using the Excel 2013 (Microsoft, Redmond, WA, USA). The statistical analysis was performed with use of the STATISTICA ver. 13.1 (Dell Inc., Round Rock, TX, USA). The results of a one-way ANOVA, followed by a Fisher's least significant difference post-hoc test (LSD), were regarded statistically significant at $P \leq 0.05$. ANOVA was performed on the assumption of normality (Shapiro-Wilk test) and homogeneity of variances (Levene's test).

\section{Results}

The herbage of the first swath was characterized by higher content of DM and a two times higher content of CP in DM, but it contained much less NDF, ADF and ADL than herbage of the second swath (Table 1). It was similar in the case of silage, but the differences between the swaths in the content of DM and NDF, increased as a result of ensiling.

Ruminal degradability of DM and OM during the individual incubation times (except for the $4^{\text {th }} \mathrm{h}$ ) was the lowest in the second swaths of herbage $(P<0.01)$ (Table 3). Ensiling the regrowth increased the ruminal degradability of DM and OM during the individual incubation times; however ensilage of the first swath increased DM and OM degradability for the first $2 \mathrm{~h}$ of incubation, whereas after $16 \mathrm{~h}$ the rate of DM and OM degradability, except OM for the $24^{\text {th }} \mathrm{h}$, were lower in silage than in herbage $(P<0.05)$.

The ensiling process resulted in a reduction of $\mathrm{CP}$ content in the silage in comparison to herbage (176 vs 199 and 97 vs 100 for the first and second swath, respectively) (Table 1). In samples prepared for in situ rumen degradability, the highest $\mathrm{CP}$ content was also found in the herbage of first swath, and the lowest in the silage of the second swath (Table 2).

Ruminal degradability of CP was similar in both swaths of herbage. Ensiling accelerated CP degradability, more than in the case of the first swath silage, in which the protein degradation occurred faster $(P<0.01)$.
Table 3. Ruminal degradability of dry matter (DM) and organic matter $(\mathrm{OM})$ including rumen incubation time and degradability constants $(A, B, C)$ in the first and second swath of Virginia fanpetals and its comparison with alfalfa silage, $\%$

\begin{tabular}{|c|c|c|c|c|c|c|}
\hline \multirow[b]{2}{*}{ Indices } & \multirow[b]{2}{*}{$\begin{array}{l}\text { Incubation } \\
\text { time, } \mathrm{h}\end{array}$} & \multicolumn{4}{|c|}{ Virginia fanpetals } & \multirow[b]{2}{*}{$\begin{array}{l}\text { Alfalfa } \\
\text { silage }\end{array}$} \\
\hline & & $\begin{array}{l}\text { herbage- } \\
1^{\text {st }}\end{array}$ & $\begin{array}{l}\text { silage- } \\
1^{\text {st }}\end{array}$ & $\begin{array}{l}\text { herbage- } \\
2^{\text {nd }}\end{array}$ & $\begin{array}{l}\text { silage- } \\
2^{\text {nd }}\end{array}$ & \\
\hline \multirow[t]{12}{*}{$\mathrm{DM}, \%$} & 0 & $24.6^{\mathrm{A}}$ & $31.5^{\mathrm{C}}$ & $24.4^{\mathrm{A}}$ & $29.4^{\mathrm{B}}$ & - \\
\hline & 2 & $32.2^{\mathrm{B}}$ & $38.3^{C}$ & $27.8^{\mathrm{A}}$ & $33.9^{\mathrm{B}}$ & 35.9 \\
\hline & 4 & $35.5^{\mathrm{A}}$ & $37.0^{A B}$ & $39.1^{A B}$ & $40.7^{\mathrm{B}}$ & 36.0 \\
\hline & 8 & $56.6^{C}$ & $53.8^{c}$ & $43.2^{\mathrm{A}}$ & $47.7^{\mathrm{B}}$ & 47.8 \\
\hline & 16 & $60.8^{\mathrm{C}}$ & $57.9^{\mathrm{B}}$ & $55.3^{A}$ & $57.4^{\mathrm{AB}}$ & 54.2 \\
\hline & 24 & $71.2^{\mathrm{C}}$ & $68.1^{\mathrm{B}}$ & - & $57.9^{\mathrm{a}}$ & 59.4 \\
\hline & 48 & $76.1^{\mathrm{D}}$ & $74.7^{\mathrm{C}}$ & $58.8^{\mathrm{A}}$ & $61.2^{\mathrm{B}}$ & 65.3 \\
\hline & 72 & $79.4^{\mathrm{D}}$ & $71.9^{c}$ & $61.2^{\mathrm{A}}$ & $63.7^{\mathrm{B}}$ & - \\
\hline & $A$ & 24.98 & 30.90 & 23.33 & 28.84 & 23.9 \\
\hline & $B$ & 52.36 & 43.17 & 37.12 & 33.57 & 42.9 \\
\hline & C & 0.077 & 0.073 & 0.109 & 0.103 & 0.064 \\
\hline & ERD & 54.3 & 54.6 & 48.2 & 50.1 & 52.4 \\
\hline \multirow[t]{12}{*}{ OM, \% } & 0 & $21.9^{A}$ & $28.1^{\mathrm{C}}$ & $21.8^{\mathrm{A}}$ & $25.6^{B}$ & - \\
\hline & 2 & $28.1^{\mathrm{B}}$ & $34.6^{\mathrm{D}}$ & $25.8^{\mathrm{A}}$ & $30.9^{c}$ & - \\
\hline & 4 & $32.3^{\mathrm{a}}$ & $33.4^{\mathrm{ab}}$ & $36.8^{\mathrm{b}}$ & $37.4^{\mathrm{b}}$ & - \\
\hline & 8 & $54.1^{\mathrm{B}}$ & $50.7^{\mathrm{B}}$ & $41.0^{\mathrm{A}}$ & $44.9^{\mathrm{A}}$ & - \\
\hline & 16 & $58.3^{B}$ & $54.9^{A}$ & $53.3^{\mathrm{A}}$ & $54.8^{\mathrm{A}}$ & - \\
\hline & 24 & $62.0^{C}$ & $65.8^{\mathrm{B}}$ & - & $55.3^{\mathrm{A}}$ & - \\
\hline & 48 & $74.6^{\mathrm{D}}$ & $73.0^{c}$ & $58.1^{\mathrm{A}}$ & $59.2^{\mathrm{B}}$ & - \\
\hline & 72 & $78.2^{\mathrm{D}}$ & $70.1^{\mathrm{C}}$ & $60.2^{\mathrm{A}}$ & $61.8^{B}$ & - \\
\hline & $A$ & 21.88 & 27.25 & 21.06 & 25.32 & - \\
\hline & $B$ & 54.45 & 45.16 & 38.41 & 35.00 & - \\
\hline & $C$ & 0.073 & 0.071 & 0.104 & 0.102 & - \\
\hline & ERD & 51.7 & 51.7 & 46.3 & 47.3 & - \\
\hline
\end{tabular}

${ }^{1}$ data reported in our previous paper (Purwin et al., 2014); $A$ - rapidly degradable fraction, $B$ - slowly degradable fraction, $C$ - rate of digestibility, ERD - effective rumen degradability; ${ }^{a b, A B}$ - means with different superscripts in the same row are significantly different at $P<0.05$ and $P<0.01$, respectively

Ensilage caused an increased solubility of NDF $(0 \mathrm{~h})$ in both the first and second swath, however, from $24 \mathrm{~h}$ of incubation, decreased NDF degradability was noted in the first swath silage.

The ensiling process contributed to an increase in the proportion of soluble fraction $(A)$ and a decrease in the proportion of insoluble but potentially degradable fraction $(B)$ of DM and OM (Table 3) and $\mathrm{CP}(P<0.01)$ (Table 4), both for the first swath and regrowth. In the ruminal degradability of NDF the proportion of both soluble and slowly degradable fraction decreased due to ensilage the first swath; however ensilage of the regrowth increased the proportion of fraction $A$ and decreased the fraction $B$.

The calculated ERD of DM and OM were numerically higher in first swath herbage and silage, and the lowest in herbage from the second swath. 
Table 4. Ruminal degradability of crude protein (CP) and neutral detergent fibre (NDF) including rumen incubation time and degradability constants $(A, B, C)$ in the first and second swath of Virginia fanpetals and its comparison with alfalfa silage, $\%$

\begin{tabular}{|c|c|c|c|c|c|c|}
\hline \multirow[b]{2}{*}{ Variable } & \multirow{2}{*}{$\begin{array}{l}\text { Incubation } \\
\text { time, h }\end{array}$} & \multicolumn{4}{|c|}{ Virginia fanpetals } & \multirow{2}{*}{$\begin{array}{l}\text { Alfalfa } \\
\text { silage }^{1}\end{array}$} \\
\hline & & $\begin{array}{l}\text { herbage- } \\
1^{\text {st }}\end{array}$ & $\begin{array}{l}\text { silage- } \\
1^{\text {st }}\end{array}$ & $\begin{array}{l}\text { herbage- } \\
2^{\text {nd }}\end{array}$ & $\begin{array}{l}\text { silage- } \\
2^{\text {nd }}\end{array}$ & \\
\hline \multirow[t]{12}{*}{$\mathrm{CP}, \%$} & 0 & $31.6^{A}$ & $68.5^{\mathrm{D}}$ & $39.1^{\mathrm{B}}$ & $55.7^{\mathrm{C}}$ & - \\
\hline & 2 & $44.2^{\mathrm{B}}$ & $74.0^{\mathrm{D}}$ & $42.6^{\mathrm{A}}$ & $59.4^{\mathrm{C}}$ & 41.1 \\
\hline & 4 & $46.9^{A}$ & $72.6^{\mathrm{D}}$ & $55.1^{\mathrm{B}}$ & $63.1^{\mathrm{C}}$ & 37.2 \\
\hline & 8 & $69.5^{\mathrm{B}}$ & $83.4^{c}$ & $63.6^{A}$ & $70.7^{\mathrm{B}}$ & 52.9 \\
\hline & 16 & $74.8^{\mathrm{A}}$ & $84.8^{\mathrm{D}}$ & $77.2^{\mathrm{B}}$ & $79.7^{c}$ & 62.7 \\
\hline & 24 & $84.3^{B}$ & $89.8^{C}$ & - & $80.0^{A}$ & 68.8 \\
\hline & 48 & $87.8^{C}$ & $90.6^{\mathrm{D}}$ & $77.8^{\mathrm{A}}$ & $79.3^{\mathrm{B}}$ & 78.2 \\
\hline & 72 & $89.8^{\mathrm{D}}$ & $87.2^{\mathrm{C}}$ & $79.0^{\mathrm{A}}$ & $79.8^{B}$ & - \\
\hline & $A$ & 32.10 & 68.21 & 36.74 & 54.34 & 31.9 \\
\hline & $B$ & 55.83 & 21.18 & 42.65 & 26.23 & 49.9 \\
\hline & C & 0.103 & 0.116 & 0.130 & 0.126 & 0.060 \\
\hline & ERD & 67.4 & 82.2 & 66.3 & 72.1 & 66.9 \\
\hline \multirow[t]{11}{*}{ NDF, $\%$} & 0 & $1.5^{\mathrm{A}}$ & $4.3^{\mathrm{B}}$ & $7.1^{c}$ & $10.1^{\mathrm{D}}$ & - \\
\hline & 4 & $4.0^{\mathrm{A}}$ & $5.6^{\mathrm{A}}$ & $14.7^{\mathrm{B}}$ & $17.0^{\mathrm{B}}$ & - \\
\hline & 8 & $23.1^{\mathrm{BC}}$ & $17.8^{A B}$ & $15.0^{A}$ & $26.4^{\mathrm{C}}$ & - \\
\hline & 16 & $27.4^{\mathrm{ab}}$ & $23.9^{\mathrm{a}}$ & $28.6^{b}$ & $29.6^{b}$ & - \\
\hline & 24 & $44.1^{\mathrm{C}}$ & $38.2^{\mathrm{B}}$ & - & $29.8^{\mathrm{A}}$ & - \\
\hline & 48 & $54.0^{c}$ & $52.1^{\mathrm{B}}$ & $35.0^{\mathrm{A}}$ & $36.5^{\mathrm{A}}$ & - \\
\hline & 72 & $60.2^{c}$ & $49.8^{B}$ & $41.1^{\mathrm{A}}$ & $41.7^{\mathrm{A}}$ & - \\
\hline & $A$ & 1.63 & 1.21 & 7.12 & 11.42 & - \\
\hline & $B$ & 67.4 & 54.4 & 33.3 & 28.1 & - \\
\hline & $C$ & 0.033 & 0.042 & 0.051 & 0.062 & - \\
\hline & ERD & 25.5 & 23.5 & 22.4 & 25.7 & - \\
\hline
\end{tabular}

${ }^{1}$ data reported in our previous paper (Purwin et al., 2014); $A$ - rapidly degradable fraction, $B$ - slowly degradable fraction, $C$ - rate of digestibility, ERD - effective rumen degradability; ab,AB - means with different superscripts in the same row are significantly different at $P<0.05$ and $P<0.01$, respectively

The ERD of CP was numerically higher in both silages than in herbages; however, in the case of the first swath, the increase in ERD of CP caused by ensilage was much greater. Contrary to the $\mathrm{CP}$ degradation, ensiling did not increase ERD of NDF in the first swath, and caused only an irrelevant increase in ERD in the regrowth.

\section{Discussion}

Virginia fanpetals silage was characterized by a lower DM content than alfalfa silage due to the ensilage of unwilted green forage. This technology was adopted after preliminary unsuccessful attempts to wilting the Virginia herbage, reported in our previous paper (Purwin et al., 2020). In the first swath of Virginia silage CP content was similar to that observed in alfalfa silage, while the content of NDF, ADF and ADL was much lower. The second swath silage was characterized by nearly times lower $\mathrm{CP}$ content, lower ADF and ADL content, and similar the NDF content to alfalfa silage.

The ensiling process positively influenced the rate of degradability of $\mathrm{DM}$ and $\mathrm{OM}$, thus increasing the value of fraction $A$ for both the first and the second swath. In comparison to the results of Purwin et al. (2014), the rumen degradability of DM in Virginia fanpetals silages in different hours of incubation was similar as in alfalfa silage (Figure 1).

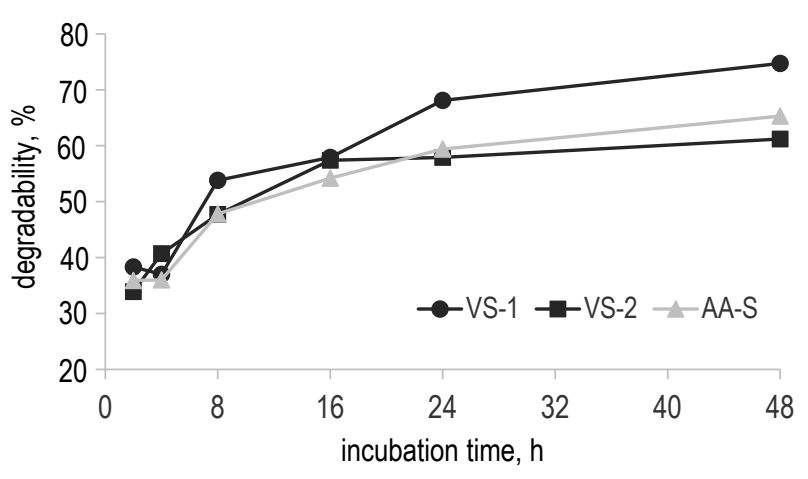

Figure 1. Dry matter ruminal degradability of Virginia fanpetals silage in the first (VS-1) and second (VS-2) swath and comparison with alfalfa silage (AA-S) from 2 to $48 \mathrm{~h}$ of incubation.

However the rapidly degradable fraction $A$ of Virginia fanpetals silages was higher and the fraction $B$ was similar or lower. The obtained ERD of the first swath silage was higher, and of the second swath silage was lower compared to alfalfa. Probably, the DM of Virginia fanpetals silages is more susceptible to ruminal degradation than the DM of alfalfa silage due to a lower content of NDF, ADF and ADL. Mustafa and Seguin (2003) analysed the DM degradability of ensiled alfalfa which was harvested in the early bloom stage and contained smaller amounts of NDF and ADF than in alfalfa analysed in our study. The examined silage was characterized by a higher proportion of fraction $A$ and higher ERD of DM than alfalfa in our study and also higher than Virginia fanpetals silage. Analysing the results of our experiment and the available data on the DM ruminal degradability of legumes (Mustafa and Seguin, 2003), it can be assumed that the content of $\mathrm{NDF}, \mathrm{ADF}$ and ADL is the main factor influencing the DM ERD of the analysed feeds.

The CP ruminal degradability of dried herbage in the present study was lower than that obtained by Tarkowski and Truchliński (2011). In that study a similar level of nitrogen fertilization $(200 \mathrm{~kg} \mathrm{~N} / \mathrm{ha})$ 
was obtained, however the degradability of DM exceed $91 \%$ after just $8 \mathrm{~h}$ of incubation in the rumen. Probably, higher degradation rate in that study was associated with a higher level of fertilization, and thus with a higher content of rapidly degradable nitrogen compounds in herbage.

Unfortunately, the ensiling process increased the dynamics of ruminal protein degradability. It was probably due to intense proteolysis processes occurring since the harvesting a forage crop until the end of the ensiling process. Therefore Virginia fanpetals silages had a much higher content of the rapidly degradable fraction $A$ than herbages. This negative effect of ensilaging was particularly evident in the case of the high-protein silage from the first swath which was characterised by more than a two-fold increase in the $A$ fraction content.

The $A$ fraction was more than two-thirds of the $\mathrm{CP}$ and was much higher than in alfalfa silage reported in our previous study (more than twice as high in the first swath) (Purwin et al., 2014). At the same time the content of the slowly degradable fraction $B$ was much lower than in herbages and also than in alfalfa silage.

However, Mustafa and Seguin (2003) revealed a higher proportion of fraction $A$ analysing the CP degradability in silage of alfalfa harvested in the early blooming stage. These results are in line with our results obtained for the first swath Virginia fanpetals silage.

The ensiling intensified the ruminal degradation of $\mathrm{CP}$, which is not beneficial from the nutritional point of view because considerable amounts of ammonia are released within a short period of time, and readily fermentable carbohydrates have to be simultaneously supplied to the rumen. The rumen degradability of CP in Virginia fanpetals silages was also considerably higher in different hours of incubation than in alfalfa silage (Figure 2) (Purwin et al., 2014).

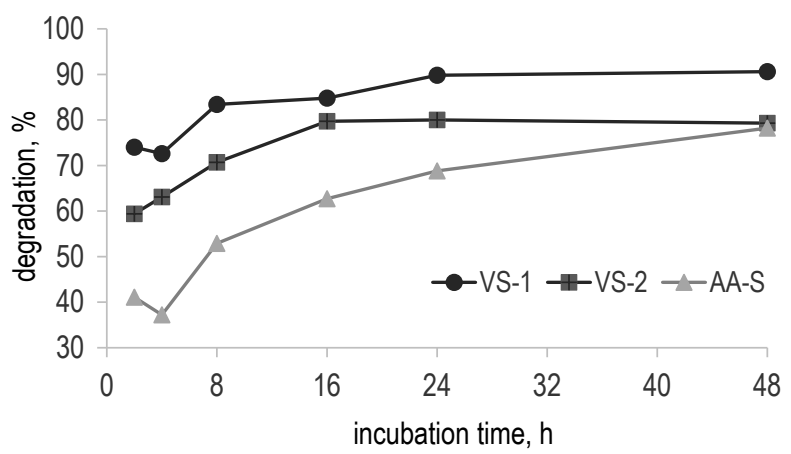

Figure 2. Crude protein ruminal degradability of Virginia fanpetals silage in the first (VS-1) and second (VS-2) swath and its comparison with alfalfa silage (AA-S) from 2 to $48 \mathrm{~h}$ of incubation
Excessive $\mathrm{CP}$ degradability can also lead to the loss of valuable essential amino acids, and it can decrease protein absorption in the small intestine. The ERD of CP in first swath Virginia fanpetals silage was 14\% higher than in regrowth and was 23\% higher than in alfalfa silage analysed in our previous study (Purwin et.al., 2014). However, Mustafa and Seguin (2003) revealed even higher ERD than for the first swath Virginia fanpetals silage in this study.

The fraction $A$ of NDF content in both the herbage and silage from the first swath was several times lower than in regrowth. The proportion of fraction $A$ of NDF in the first swath Virginia fanpetals silage was also more than four-times lower than that determined by Mustafa and Seguin (2003) in ensiled alfalfa harvested in the early blooming stage. However, the content of non-degradable NDF was also lower in Virginia, therefore the ERD of NDF was only about $14 \%$ lower in the first swath Virginia fanpetals silages than in alfalfa silage in Mustafa and Seguin (2003) study. Ensiling decreased the content of NDF at the first swath, and its fractions $A$ and $B$, relative to herbage, and this change lowered the NDF ERD. This modification could have been attributed to a series of reactions triggered by a high increase in the temperature of the ensiled substrate. At the same time, the ADF content was slightly increased in silage from both swath, which was probably the result of a change in the proportions.

\section{Conclusions}

The results of the present study, which investigated the rumen degradability of silage made from the first swath and regrowth of Virginia fanpetals confirmed that such silage can be used not only as a source of renewable energy but also as a supplementary forage for ruminants. In particular, the first swath silage, due to its high protein content, can be used instead of legume silage in diets for cattle, and also it can reduce the need to use high-protein concentrate. Unfortunately, ensiling caused significant increase in the rate of rumen protein degradability, which with unchanged dry matter and fibre degradability rate is not a desirable effect and requires simultaneous delivery of quickly digested carbohydrates into ruminant diets.

\section{Acknowledgments}

This research was partially funded by a programme BIOSTRATEG funded by the National Centre for Research and Development in Poland; 
grant No. BIOSTRATEG 1/270745/2/NCBR/2015, entitled 'Dietary, power and economic potential of Sida hermaphrodita cultivation on fallow land' (acronym SIDA).

\section{References}

AOAC International, 2005. Official Methods of Analysis of AOAC International. $18^{\text {th }}$ Edition. AOAC International, Gaithersburg, MD (USA)

Bandyukova V.A., Ligai L.V., 1987. Study of the kinetics of the extraction of flavonoids from plant raw material I. Extraction of rutin from Sida hermaphrodita. Chem. Nat. Comp. 23, 551-553, https://doi.org/10.1007/BF00598669

Borkowska H., 1994. Anti-nutritional substances in the leaves and roots of Sida (in Polish). Biul. Naukowy Przem. Pasz. 3/4, 49-52

Calsamiglia S., Ferret A., Reynolds C.K., Kristensen N.B., van Vuuren A.M., 2010. Strategies for optimizing nitrogen use by ruminants. Animal 7, 1184-1196, https://doi.org/10.1017/ S1751731110000911

Frank B., Persson M., Gustafsson G., 2002. Feeding dairy cows for decreased ammonia emission. Livest. Prod. Sci. 76, 171-179, https://doi.org/10.1016/S0301-6226(02)00021-0

Fijałkowska M., Przemieniecki S.W., Kurowski T., Lipiński K., Nogalski Z., Purwin C., 2017. Ensiling suitability and microbiological quality of Virginia fanpetals biomass. Can. J. Anim. Sci. 97, 541-544, https://doi.org/10.1139/cjas-2016-0175

Ganeshpurkar A., Saluja A.K., 2017. The pharmacological potential of rutin. Saudi Pharm. J. 25, 2, 149-164, https://doi. org/10.1016/j.jsps.2016.04.025

INRA, 2007. Nutrition of Cattle, Sheep and Goats: Animal Needs Feed Values. Quae Editions, Paris (France)

Manning D.B., Bemmann A., Bredemeier M., Lamersdorf N., Ammer C., Bemman A., 2015. Bioenergy from dendromass for the sustainable development of rural areas. John Wiley \& Sons. Hoboken, NJ (USA), https://doi.org/10.1002/9783527682973

Michalet-Doreau B., Vérité R., Chapoutot P., 1987. Methodology of estimating degradability in sacco of nitrogen in feed in the rumen. Bull. Tech. CRZV Theix 69, 5-7

Mustafa A.F., Seguin P., 2003. Ensiling characteristics, ruminal degradabilities and whole tract nutrient utilization of berseem clover (Trifolium alexandrium L.) silage. Can. J. Anim. Sci. 83, 147-152, https://doi.org/10.4141/A02-050
OJEU (Official Journal of the European Union), 2010. Directive 2010/63/EU of the European Parliament and of the Council on the Protection of Animals Used for Scientific Purposes; OJEU 20.10.2010, Series L 276; OJEU, Brussels (Belgium), 33-79

Oleszek M., Matyka M., Lalak J., Tys J., Paprota E., 2013. Characterization of Sida hermaphrodita as a feedstock for anaerobic digestion process. J. Food Agric. Environ. 11, 1839-1841

Ørskov E.R., McDonald P., 1979. The estimation of protein degradability in the rumen from incubation measurements weighted according to rates of passage. J. Agric. Sci. 92, 499-503, https://doi.org/10.1017/S0021859600063048

Porter M.G., Murray R.S., 2001. The volatility of components of grass silage on oven drying and the inter-relationship between drymatter content estimated by different analytical methods. Grass Forage Sci. 56, 405-411, https://doi.org/10.1046/ j.1365-2494.2001.00292.x

Purwin C., Fijałkowska M., Kowalik B., Skórko-Sajko H., Nogalski Z., Pysera B., 2014. The effect of bale density and addition of formic acid on the in situ dry matter and crude protein degradation of lucerne, red clover and red fescue silages. J. Anim. Feed Sci. 23, 177-184, https://doi.org/10.22358/ jafs/65707/2014

Purwin C., Nogalski Z., Starczewski M., Czurgiel S., Fijałkowska M., Momot M. and Borsuk M., 2020. Effects of dietary substitution of alfalfa silage with Virginia fanpetals silage in lactating Polish Holstein Friesian dairy cows. Animals 10, 1746, https:/l doi.org/10.3390/ani10101746

Sullivan M.L., Hatfield R.D., Samac D.A., 2008. Cloning of an alfalfa polyphenol oxidase gene and evaluation of its potential in preventing postharvest protein degradation. J. Sci. Food Agric. 88, 1406-1414, https://doi.org/10.1002/jsfa.3232

Tarkowski A., 2008. The yield and chemical composition of milk of cows fed the ration with protein-fibrous extruderate. J. Cent. Eur. Agric. 9, 645-650

Tarkowski A., Truchliński J., 2011. Nutritional value of Virginia fanpetals (Sida hermaphrodita Rusby) protein in evaluation of nitrogen fertilization effect on environment. New Med. 1, 8-11

Thomas T.A., 1977. An automated procedure for the determination of soluble carbohydrates in herbage. J. Sci. Food Agric. 28, 639-642, https://doi.org/10.1002/jsfa.2740280711

Van Soest P.J., 1994. Nutritional ecology of the ruminant. 2nd Edition. Comstock Publishing Associates, Division of Cornell University Press. London (UK), https://doi.org/10.7591/9781501732355

Van Soest P.J., Robertson J.B., Lewis B.A., 1991. Methods of dietary fiber, neutral detergent fiber and nonstarch polysaccharides in relation to animal nutrition. J. Dairy Sci. 74, 3583-3597, https://doi.org/10.3168/jds.S0022-0302(91)78551-2 